\title{
Transformational Leadership and Organizational Culture of Educational Institutions along Thai-Lao borders
}

\author{
Surapee Akomkong \& Vichian Puncreobutr \\ St.Theresa International College, Thailand
}

\begin{abstract}
The purpose of this study was to measure the Transformational Leadership and Organizational Culture of Educational Institutions along the Thai-Lao borders at Bueng Kan province. The target respondents for the study are students' parents and Thai teachers in schools along Thai-Lao borders and the estimated sample size for the study is 384 . The statistical tools used for the study are mean, T-test and Pearson's simple correlation. The results of the study furnished that the existence of transformational leadership and organizational culture is at high level in schools along Thai-Lao borders. Besides, among the parents and teachers, parent's agreeableness is high towards transformational leadership and organizational culture. And the correlation results indicate that there is a positive significant relationship (.639) between transformational leadership and organizational culture. Conclusion and suggestions are presented for applications in future research.
\end{abstract}

Keywords: transformational leadership; organizational leadership; educational administrators; Bueng Kan Province

\section{Introduction}

Bueng Kan Province is the 77th province of Thailand bordering with Lao PDR and connecting with a distance of 330 kilometers long with Mekong River as a border river. There is one border crossing or check- point which is also the location of the permanent customs office. Bueng Kan province is located opposite to the city of Pakxan in Bolikhamxai province of Lao PDR. Bung Karn is with a gross domestic product (GPP: Gross Province Product) of more than 20,00o million baht, with a border trade worth more than 4,300 million baht and the trade volume is increased annually, (Bureau of Cooperation on Trade and Investment, Foreign Trade Department 2014). In addition, the opening up of free trade under the General Agreement on Trade in Services (General Agreement on Trade in Services, or GATS) has determined that trade, services and education services, are also branches of the trade liberalization and negotiations. In addition, the free trade opening with educational services will not only create benefits to educational development, but also will be conducive to the growth of trade and economy of the country (Suwannee Khammun, 2002). However, school administrators living along Thai-Lao borders in Bung Karn province should understand the opening up of liberal (free) education and adjust themselves accordingly in terms of both transformational leadership (Bass, 1985) and organizational culture administration (Denison, 1990; Cameron and Quinn, 1999; Daft, 2008; Slocum and Hellriegel, 2011; Ivancevich, Konopaske and Matterson, 2011) appropriately. 
As transformational leadership, and organizational culture issues are extensively focusing on working style, performance and the resulting outcomes, the researcher recognized that there should be a study on the relationship between transformational leadership and organizational culture of educational institution (school) administrators along Thai-Lao borders at Bueng Kan province. This will also be useful for preparing the schools and educational administrators to cope up with the opening up of free education in the near future.

\section{Objectives of the research}

- To study the level of transformational leadership of the educational institution administrators in schools along Thai-Lao borders at Bueng Kan Province.

- To understand the level of organizational culture of educational institution administrators in schools along Thai-Lao borders at Bueng Kan Province.

- To compare the level of transformational leadership of educational institution administrators based on category of respondents.

- To compare the level of organizational culture of educational institution administrators based on category of respondents.

- To measure the relationship between transformational leadership and organizational culture of educational institution administrators.

\section{Research Methodology}

The target population of the study were 100,000 in approximate consisting of students' parents and teachers, who live along the Thai-Lao borders at Bueng Kan province. The estimated sample size of the study is 384 based on Krejcie and Morgan table. The sampling method adopted for the study is simple random sampling.

\section{Variables of the study}

The dependent variables are 1) Transformational leadership, of administrators in educational institutions, adopting the concept of Bass (1985), which consists of Idealized Influence (II), Inspirational motivation (IM), Intellectual Stimulation (IS) and Individualized Consideration (IC) 2) Organizational culture is based on the concept of Denison (1990); Cameron and Quinn (1999); Daft (2008); Slocum and Hellriegel (2011); Ivancevich et.al (2011), which consists of Adaptation, Involvement, Structure \& Regulations, Mission and Social Responsibility. The research instrument was constructed and tested for reliability. The discrimination value ranges from $.40-.82$ and the Cronbach alpha value at .87 , which holds high reliability. The statistical tools used in this study are Mean, T-Test and Pearson's simple correlation.

\section{Data Analysis and Interpretation}

\section{Basic data}

The respondents were classified based on the category. And it is found that 157 respondents were Thai teachers accounted for 40.9 percent and 277 respondents were students parents at 59.1 
percent respectively. Hence there is around 10 percent gap between the sample groups of the respondents.

\section{Level of transformational leadership}

The level of transformational leadership of educational institution administrators in schools along Thai-Lao borders, as shown in the Table 1.

Table 1 shows the overall level of Transformational Leadership $(\mathrm{N}=384)$

\begin{tabular}{|l|r|r|c|}
\hline \multicolumn{1}{|c|}{ Items } & Mean & S.D. & $\begin{array}{c}\text { Level of transformational } \\
\text { leadership }\end{array}$ \\
\hline Idealized Influence (II) & 4.485 & .4767 & High \\
\hline Inspirational motivation (IM) & 4.252 & .5972 & High \\
\hline Intellectual Stimulation (IS) & 4.362 & .5990 & High \\
\hline Individualized Consideration (IC) & 4.487 & .6083 & High \\
\hline Transformational Leadership & 4.397 & .4546 & High \\
\hline
\end{tabular}

From the Table 1, it is found that the level of transformational leadership of educational institution administrators in schools along the Thai-Lao borders is at the high level (By average 4.397). While considering each aspect of transformational leadership, it is found that all aspects scores high. The result indicates that among all aspects of transformational leadership, Individualized Consideration (IC) scores high followed by Idealized Influence (II), Intellectual Stimulation (IS) and Inspirational Motivation (IM) respectively.

\section{Level of Organizational Culture}

The level of organizational culture of the educational institutions along the Thai - Lao border is shown in Table 2

Table 2 shows the overall level of Organizational Culture $(\mathrm{N}=384)$.

\begin{tabular}{|l|r|r|c|}
\hline \multicolumn{1}{|c|}{ Items } & Mean & \multicolumn{1}{c|}{ S.D. } & $\begin{array}{c}\text { Level of organizational } \\
\text { culture }\end{array}$ \\
\hline Adaptation & 4.290 & .5884 & High \\
\hline Involvement & 4.372 & .6208 & High \\
\hline Structure and Regulations & 4.400 & .5113 & High \\
\hline Mission & 4.276 & .6010 & High \\
\hline Social Responsibility & 4.283 & .6311 & High \\
\hline Organizational Culture & 4.324 & .4540 & High \\
\hline
\end{tabular}

From the Table 2, it is inferred that the level of Organizational Culture of educational institutions along the Thai-Lao borders is at high level (By average 4.324). While considering each aspect or of organizational culture, it is found that all aspects scores eventually high. The result indicates that among all aspects of organizational culture, Structure and Regulations scores high level, followed by Involvement, Adaptation, Social Responsibility and Mission respectively.

Table 3 Comparison of Transformational Leadership with respondents' category

\begin{tabular}{|l|c|c|c|c|c|c|}
\hline \multirow{2}{*}{ Items } & \multicolumn{2}{|c|}{ Teacher (N=157) } & \multicolumn{2}{c|}{ Parents(N=22) } & \multirow{2}{*}{$\mathrm{t}$} & $\mathrm{P}$ \\
\cline { 2 - 7 } & Mean & S.D. & Mean & \multicolumn{1}{c|}{ S.D. } & & \\
\hline Idealized Influence (II) & 4.299 & .5122 & 4.614 & .4040 & $-6.446^{* *}$ & .000 \\
\hline Inspiration motivation (IM) & 4.003 & .5640 & 4.425 & .5584 & $-7.249^{* *}$ & .000 \\
\hline
\end{tabular}




\begin{tabular}{|l|r|r|r|r|r|r|}
\hline Intellectual Stimulation (IS) & 4.192 & .6328 & 4.480 & .5456 & $-4.752^{* *}$ & .000 \\
\hline Individualized Consideration (IC) & 4.347 & .7000 & 4.584 & .5154 & $-3.628^{* *}$ & .000 \\
\hline Transformational Leadership & 4.210 & .4619 & 4.526 & .4027 & $-7.105^{* *}$ & .000 \\
\hline
\end{tabular}

${ }^{*} \mathrm{p}<.05{ }^{* *} \mathrm{p}<.01$

From the Table 3, it is examined that there is a significant difference among the category of respondents towards transformational leadership of educational institution administrators in schools along the Thai - Lao borders at Bung Karn province. While comparing parents and teachers, the mean score for parents group is very high with respect to transformational leadership of educational administrators. The $\mathrm{p}$-value $(\mathrm{P}<0.01)$ indicates that significant difference exists among the category of respondents.

Table 4 Comparison of Organizational Culture with respondents' category

\begin{tabular}{|c|c|c|c|c|c|c|}
\hline \multirow{2}{*}{ Items } & \multicolumn{2}{|c|}{ Teacher $(\mathrm{N}=157)$} & \multicolumn{2}{|c|}{ Parents $(\mathrm{N}=227)$} & \multirow{2}{*}{$\mathrm{t}$} & \multirow{2}{*}{$\mathrm{P}$} \\
\hline & Mean & S.D. & Mean & S.D. & & \\
\hline Adaptation & 4.001 & .5514 & 4.490 & .5281 & $-8.75^{* *}$ & .000 \\
\hline Involvement & 4.270 & 6379 & 4.442 & .6000 & $-2.661^{* *}$ & .008 \\
\hline Structure and Regulations & 4.259 & .5218 & 4.497 & .4814 & $-4.606^{* *}$ & .000 \\
\hline Mission & 4.055 & .7080 & 4.428 & .4573 & $-5.810^{* *}$ & .000 \\
\hline Social and Responsibility & 4.197 & .6176 & 4.343 & .6348 & $-2.243^{*}$ & .025 \\
\hline Organizational Culture & 4.157 & .4347 & 4.440 & .4312 & $-6.313^{* *}$ & .000 \\
\hline
\end{tabular}

${ }^{*} \mathrm{p}<.05{ }^{* *} \mathrm{p}<.01$

From the Table 4, it is examined that there is a significant difference among the category of respondents towards organizational culture in educational institutions along the Thai - Lao borders at Bueng Kan province. While comparing parents and teachers, the mean score for parents group is very high with respect to the organizational culture in educational institutions. The p-value $(\mathrm{P}<0.01)$ indicates that significant difference exists among the category of respondents.

Table 5 Relationships between Transformational Leadership and Organizational Culture

\begin{tabular}{|l|c|c|c|c|c|}
\hline & II & IM & IS & IC & Leadership \\
\hline Adaptation & $.300^{* *}$ & $.461^{* *}$ & $.581^{* *}$ & $.628^{* *}$ & $.633^{* *}$ \\
\hline Involvement and & $.170^{* *}$ & $.210^{* *}$ & $.288^{* *}$ & $.368^{* *}$ & $.332^{* *}$ \\
\hline $\begin{array}{l}\text { Structure } \\
\text { Regulations }\end{array}$ & $.378^{* *}$ & $.458^{* *}$ & $.385^{* *}$ & $.482^{* *}$ \\
\hline Mission and & $.343^{* *}$ & $.479^{* *}$ & $.439^{* *}$ & $.366^{* *}$ & $.538^{* *}$ \\
\hline $\begin{array}{l}\text { Social } \\
\text { Responsibility }\end{array}$ & & $.409^{* *}$ & $.295^{* *}$ & $.456^{* *}$ \\
\hline Organizational Culture & $.402^{* *}$ & $.505^{* *}$ & $.568^{* *}$ & $.534^{* *}$ & $.639^{* *}$ \\
\hline
\end{tabular}

** $\mathrm{p}<.01$

Table 5 reveals the relationship between transformational leadership and organizational culture in schools along the Thai- Lao borders at Bung Karn province. The relationship between transformational leadership and organizational culture is highly correlated, the correlation coefficient at .639, with the statistical significance value of $\mathrm{P}<0.01$. Whereas the relationship between various aspects of transformational leadership and organizational culture reports only few are highly correlated i.e. Adaptation \& Individualized consideration at .628 and Adaptation \& 
Intellectual stimulation at .581. All other aspects are moderately correlated and the item involvement is least correlated with the aspects of transformational leadership. Moreover, all items are positively correlated, but there is no strong relationship for some items.

\section{Discussion}

The study findings indicate that transformational leadership of educational institutions administrator in schools along the Thai-Lao borders is at high level. While considering various aspects of transformational leadership, the mean value scores high among both parents and teachers. Moreover when comparing mean scores of parents and teachers, the mean score of parents is high, means they agree that transformational leadership prevailing in schools is at high level. And the t-test results indicates that there is a significant difference exist among the parents and teachers at $\mathrm{P}<0.01$ level.

The findings for organizational culture of educational institutions portraits that overall mean score is high including parents and teachers. Hence organizational culture is prevailing high in educational institutions. While comparing with the opinion of parents and teachers, the mean score for parents' category is high towards organizational culture. And the result of t-test indicates that there is a significant difference exist among the parents and teachers at $\mathrm{P}<0.01$ level.

The results of Pearson correlation portraits that the relationship between transformational leadership and organizational culture in educational institutions is highly correlated with correlation coefficient of .639 at significance level .o1. While considering various aspects of transformational leadership and organizational culture, it is found that adaption and individualized consideration is highly correlated, whereas other aspects are moderately correlated and involvement is least correlated with the aspects of transformational leadership. Overall positive correlation exists among transformational leadership and organizational culture, but there is no strong association among the variables.

\section{Conclusion}

Transformational leadership and organizational culture is high in educational institutions along Thai-Lao borders, Bueng Kan Province. And when compared to Thai teachers, parents agreed transformational leadership and organizational culture is prevailing high at educational institutions. Moreover, the overall relationship between transformational leadership and organizational culture and is high, but the various aspects of them are not strongly associated. Though, the educational administrators are able to cope up with changes and leading towards the growth for inculcating strong organizational culture through transformational leadership.

\section{Suggestions}

The suggestions may facilitate educational administrators at Bueng Kan province to improve various aspects of transformational leadership and organizational culture among both parents and teachers. The various aspects with discrepancies can be improved to derive strong relationship between transformational leadership and organizational culture. The strengths of the Transformational Leadership and Organizational Culture should be considered for further applications in educational management to support the internationalization of free trade in services as well as the growth of economy in the near future. 


\section{Acknowledgement}

The authors acknowledge the help of Dr.Tanat Titiworatat and Dr.Vichian Puncreobutr, Lecturers, St.Theresa International College, Thailand for the contextual data and conceptualization of the study.

\section{References}

The Bureau of Cooperation on Trade and Investment, Foreign Trade Department. (2014). Bung Karn and its Opportunities on Trade and New Logistics Route. Bangkok: Publication.

Suwannee Kamman. (2002). Liberalization of Education: The Way to a Regional Education Hub. Economy and society Journal. 39 (5), 71-74.

Bass. (1985). Leadership and Performance Beyond Expectations. New York: Free Press.

Cameron, S. K. and Quinn, E. R. (1999). Diagnosing and Changing Organizational Culture: Based on the Competing Value Framework. New York: Addison-Wesley.

Daft, R. L. (2008). The Leadership Experience. $4^{\text {th }}$ ed. Mason, O.H.: Thomson/South-Western.

Denison, R. D. (1990). Corporate Culture and Organizational Effectiveness. Canada: John Willey \& Sons.

Ivancevich, M. J., Konopaske, R. and Matterson, M. T. (2011). Organizational Behavior and Management. $9^{\text {th }}$ ed. New York: McGraw-Hill.

Slocum, J. W. and Hellriegel, D. (2011). Principles of organizational Behavior. $13^{\text {th }}$ ed. Mason, OH: Southwestern Cengage Learning.

Dr.Surapee Akomkong is Lecturer-M.Ed. Thai Program, St. Theresa International College, Thailand.

Dr.Vichian Puncreobutr is Lecturer-M.Ed. English Program, St. Theresa International College, Thailand. 